\title{
Pandemic: lessons for today and tomorrow?
}

\section{Arthur Bakker $^{1} \cdot$ David Wagner ${ }^{2}$}

Published online: 26 March 2020

(C) Springer Nature B.V. 2020

A pandemic is currently grinding public life to a halt. Schools and universities are closed in many countries. Conferences are canceled or postponed. We empathize with people who have lost dear ones or turned ill, and with those who struggle to keep life going, for themselves and their dear ones. Organizers of many conferences have seen their huge efforts evaporate by one single decision, necessary to slow down the spread of the Covid-19 virus. Many participants had already booked flights and hotels - all gone. What will happen to all the research insights currently written down in ICME and PME papers?

In this editorial, we raise the question, What are the consequences for mathematics education and for research, now and in the future? Informal email conversation with colleagues across the globe (including China and Italy) points to many challenges and concerns that relate to life and to education. Most of the challenges are transdisciplinary, but some have unique characteristics for mathematics learning. There is research on mathematics learning at a distance through non-traditional media, but we expect that the consequences of this pandemic will inspire more such research. Many of our conversations these days turn to deep reflection in an attempt to stay calm and clear-headed. In this editorial, we summarize a few experiences that people have shared with us, hoping that proper study will help people formulate lessons for today and tomorrow. This is particularly challenging in times where change is so rapid. As educators and researchers, we find ourselves in a tension eloquently formulated by Søren Kierkegaard: "It is perfectly true, as the philosophers say, that life must be understood backwards. But they forget the other proposition, that it must be lived forwards" (1843/2019, Journals IV A 164).

\section{Some challenges}

The current situation reminds us of Dante's Divina Commedia written in the 1300s. It starts with Dante lost in a dark wood, unable to find the right way (la diritta via). We ourselves wrestle with mundane questions about food, exercise, and navigating formerly simple human

Arthur Bakker

A.Bakker4@uu.nl

1 Utrecht University, Princetonplein 5, 3584 CC Utrecht, The Netherlands

2 University of New Brunswick, Fredericton, Canada 
interactions without touching each other. At the same time, we struggle to prioritize our efforts in the crisis, with imperatives from our institutions balanced against our important human relationships while our loved ones struggle with the crisis themselves. We look for the right way, and wonder how to evaluate what is right in this unfamiliar situation.

From one moment to the next, teachers are compelled to make decisions on how to encourage their students to continue their learning at a distance. For those with access to the internet and good resources, the challenges are big enough, even when highly educated parents are willing to help at home. However, many colleagues all over the world worry that inequality and the digital divide will only increase, because many students do not have the resources and opportunities to engage in online education. With millions of people suddenly using online platforms, crashing software or poor access is all too common. And what if parents, in particular of young children, have to work outside, say in health care?

Several colleagues worried that quick adoption of new technology will lead to falling back to less favorable pedagogy (e.g., transmission of knowledge or the laissez faire of unguided discovery). Questions were also raised what it meant to lose some embodied aspects of learning and the face-to-face interaction with peers and teachers. Who is going to diagnose and respond to students' levels and needs, when there is so much online material to choose from? How will student teachers get the credits for traineeships? How should examination be organized? An interesting story on using technology was provided by Ivy Kidron (Israel), who reported about a request from a first-year student in Calculus to his lecturer: "Please, even when you use technological tools, please, send us a copy of your hand-written notes. It will be like when you write on the blackboard."

Face-to-face communication is important for many colleagues, in particular for young scholars who want to make new friends and get to know the field. But senior colleagues, too, stressed how happy they were with emails from all over the world asking about their situation. Fortunately, some conferences managed to continue through an online platform. Educators in Japan even managed to organize an online conference dinner!

In abstract terms, traditional boundaries between practices suddenly change. New boundaries are formed: physical distance and lack of easy communication and access. However, some boundaries fall away. Erasmus' saying that "space separates bodies, not minds" gains new meaning five centuries later. We have seen ourselves how parents and siblings become more involved in children's education. The typical boundaries between school and out-of-school contexts (Bronkhorst \& Akkerman, 2016) can thus quickly become permeable if the situation requires it. However, permeable boundaries are not always appreciated: Colleagues also lamented disappearing work-home boundaries: Work is not really work anymore, and home is not just home anymore. Many of us feel imprisoned at home. In the news, we saw how Iran freed 85,000 prisoners, and inmates in Italy protested that they cannot see their relatives. Daniela Ferrarello made a video for Italian inmates to explain the situation, and noted that suddenly "there is no more "we and you' but only 'we'." What is "togetherness" in this day and age? And "freedom"? Perhaps freedom can be sought in the mind rather than in doing whatever one likes to do.

We have read about ethical dilemmas that mathematics education researchers have faced or are facing. Everyone's first priority is to care about their local circumstances. Educators may assist schools in setting up new learning arrangements to continue mathematics education at a distance. How important is it that data collection by researchers continues? That their papers are submitted? Research on the current situation will be useful for the future, but does one get approval from ethical review boards so quickly? And is it fair to burden people who have more urgent challenges than engaging in research? What exactly is it that we as a research 
community have to offer in such times of crisis? Researchers with experience in distance education suddenly are in a position that their expertise is much wanted, almost everywhere. Educators who have thought deeply about how to teach mathematical modeling or exponential and logistic functions find the relevancy of their insights confirmed. Some researchers have already worked on risk and so-called disaster mathematics. The didactics and domain-specific pedagogy of many mathematical and statistical topics are crucial in times where far-reaching measures have to be explained to large populations. The current situation asks for mathematical and statistical literacy of a large population, as the media use all kinds of representations and simulations to explain why the spread of the virus has to be slowed down, and why isolation is so important so as to keep numbers within the capacity of the health care system ("flatten the curve"). One nice example can be found in The Washington Post: https://www. washingtonpost.com/graphics/2020/world/corona-simulator/.

\section{Some hope}

For almost everyone, the crisis is a disaster. However, we are reminded by lessons from millennia-old wisdom traditions. For example,

There is a time for being ahead,

a time for being behind;

a time for being in motion,

a time for being at rest;

a time for being vigorous,

a time for being exhausted;

a time for being safe,

and a time for being in danger. (Tao Te Ching-Mitchell, 1988, 29)

We are reading on social media that during the Great Plague, a pandemic from 1665 to 1666 in England, Isaac Newton fled from Trinity College to his parents in the countryside when the University of Cambridge had to close for almost 2 years. Newton claimed to have made some of his major discoveries in that period, though the stories in the literature are sometimes exaggerated (Westfall, 1980). We know that some people have the luxury of time for reflection, while others are compelled to act on and in the crisis. Others may be forbidden to act or work, but even then people tend to be creative. During World War II, for example, Hans Freudenthal, as a Jew, was not allowed to work at the university; it was in those days that his interest in mathematics education at primary school level was sparked by "playing school" with his children - an interest that was further fueled by conversations with his wife (la Bastide van Gemert, 2006, 2015). One may argue that without Hans Freudenthal, there would have been no Educational Studies in Mathematics (Beckers, 2019).

It is a consolation to read that disasters and crises tend to bring out the best in people (Bregman, 2020), and to see through the news and social media wonderful examples of creativity, humor, selflessness, and humanity. Whether or not we have more time to think, we hope that this pandemic will prompt us all to reflect on what is most important in life, education, and research, as it disrupts our habits and our habitual ways of thinking. We are reminded that the relation between the individual and the collective is rethought across cultures (e.g., China, South Korea, and Italy), yet universally, there seems to be agreement that the collective has to prevail in this global crisis. 
We find beauty and possibilities even in this time of challenges. In general, everyone seems to be on a very steep learning curve when it comes to using digital tools and finding creative solutions to practical problems. Educators invent new educational games. Some publishers have made their curricula available online, for free, including accompanying educational software. Curricular authors have redesigned learning activities so as to explain the relation of the current pandemic and exponential coefficients in mathematical models. Friends and colleagues speculate that this crisis is driving our post-fact society back to trust in science. Many colleagues stress that they see increased interest in mathematics and statistics that are useful in addressing real problems. After all, these disciplines have their ways of scientific handling of uncertainty. We can begin to speculate on how the status of teachers - until now rather low in some countries - will change, now that many parents and caregivers engage more in their children's education and learning.

In short, there is a need for research on many different topics. We need to curate lessons that people have learned or are going to learn about the current situation, for the benefit of future crises and times of stability. We assume, with the French sculptor Auguste Rodin, that time is not wasted if the experience is used wisely. To stimulate the sharing of experience, anchored in literature and preferably also based on empirical data, we announce an upcoming special issue of Educational Studies in Mathematics on Mathematics education in a time of crisis - a viral pandemic, to be guest-edited by Man Ching Esther Chan, Cristina Sabena, and David Wagner (see the journal's website and the back matter of Volume 103, Issue 3). We wish everyone well.

Acknowledgments We are grateful to the following people for the email conversations we had with them: Lianchun Dong, Li Jian, Li Haidong, Xiaotian Sun (from China); Ferdinando Arzarello, Mariolina Bartolini, Daniela Ferrarello, Fulvia Furinghetti, Maria Alessandra Mariotti, Maria Mellone, Ornella Robutti, Cristina Sabena (Italy); Yutaka Kondo, Nagisa Nakawa, Yusuke Shinno (Japan); Taro Fujita (Japan and UK); Nadá Vondrová (Czech Republic); Michèle Artigue, Viviane Durand-Gerrier, Corinne Hahn, Alain Kuzniak (France); Angel Gutiérrez (Spain); Angelika Bikner-Ahsbahs, Stanislaw Schukajlow (Germany); Tommy Dreyfus, Ivy Kidron (Israel), Dor Abrahamson (USA); and Anna Shvarts (the Netherlands).

\section{References}

Beckers, D. (2019). Why to publish on mathematics education so as to be useful? Educational Studies in Mathematics and its founder Hans Freudenthal. Educational Studies in Mathematics, 101, 7-17. https:/doi. org/10.1007/s10649-019-9881-4

Bregman, R. (2020). Don't forget: Disasters and crises bring out the best in people. The Correspondent. $\mathrm{https}$ //thecorrespondent.com/350/dont-forget-disasters-and-crises-bring-out-the-best-in-people/46307515100$1 \mathrm{~b} 82207 \mathrm{~d}$.

Bronkhorst, L. H., \& Akkerman, S. F. (2016). At the boundary of school: Continuity and discontinuity in learning across contexts. Educational Research Review, 19, 18-35.

Kierkegaard, S. (2019). Kierkegaard's Journals and Notebooks: Volume 11: Part 1, Loose Papers, 1830-1843. Princeton, NJ: Princeton University Press.

La Bastide-van Gemert, S. (2006). “Elke positieve actie begint met critiek”: Hans Freudenthal en de didactiek van de wiskunde. Hilversum, the Netherlands: Uitgeverij Verloren.

La Bastide-van Gemert, S. (2015). All positive action starts with criticism: Hans Freudenthal and the didactics of mathematics (translated by M. Vincken \& W. Third). Dordrecht, the Netherlands: Springer.

Westfall, R. S. (1980). Newton's marvelous years of discovery and their aftermath: Myth versus manuscript. Isis, 71(1), 109-121.

Publisher's note Springer Nature remains neutral with regard to jurisdictional claims in published maps and institutional affiliations. 